\title{
Case Study on Deformation Control of Upper-Soft and Lower-Hard Large Span Tunnel Station Using Combined Control Technology and Monitoring Demonstration
}

\author{
(Kajian Kes Kawalan Ubah Bentuk Lembut-Atas dan Keras-Bawah Stesen Terowong Jangka \\ Panjang Menggunakan Teknologi Kawalan Gabungan dan Demonstrasi Pemantauan)
}

\author{
Yanliang Shang, Shouji Du*, Tongyin Han \& Biao Shao
}

\begin{abstract}
A large number of shallow buried tunnels are built in the city nowadays and the special strata such as large upper-soft and lower-hard ground often encountered. Deformation control of strata is the focus issue related to the construction safety. Based on Dalian metro Hing Street station with the classical geological condition of upper-soft and lower-hard ground, this paper fully used a combined control method including six different support measures to control the deformation of surrounding rock. 3D finite element model was setup to analyze the construction effect of combined control measures and the monitoring in-site was carried out to verify the deformation control effect of combined control method. It shows that the maximum surface subsidence value is gradually reduced with the support measures gradually increasing. In the case of various supports the maximum sedimentation value is $2.67 \mathrm{~cm}$, which is $42.1 \%$ lower than that of not using control method and the control effect is obvious. In addition, it can be seen that the two-layer initial support and additional large arch foot have the best effect on controlling the ground surface settlement with reduction of $11.7 \%$ and $20.2 \%$, respectively. The research results can provide practical experience for the construction of such tunnels, and guide the design and construction of the tunnel in the future.
\end{abstract}

Keywords: Combined control method; deformation monitoring large-span tunnel; rock deformation; upper-soft and lower-hard ground; 3D numerical simulation

ABSTRAK

Pada masa ini, sebilangan besar terowong bawah tanah telah dibina di bandar dan strata khas seperti tanah lembutatas dan keras-bawah sering ditemui. Kawalan ubah bentuk strata merupakan isu yang berkaitan dengan keselamatan pembinaan. Berdasarkan stesen Dailan Metro Hing Street dengan keadaan geologi klasik tanah lembut-atas dan kerasbawah, kajian ini menggunakan sepenuhnya kaedah kawalan gabungan termasuklah enam langkah sokongan yang berbeza untuk mengawal ubah bentuk batu sekitaran. Model unsur 3D terhingga adalah persediaan untuk menganalisis kesan pembinaan langkah kawalan gabungan dan pemantauan tapak telah dijalankan untuk mengesahkan kesan kawalan ubah bentuk terhadap kaedah kawalan gabungan. Ia menunjukkan bahawa nilai maksimum permukaan amblesan telah mengalami penurunan dan nilai ukuran sokongan mengalami peningkatan. Dalam kes sokongan yang pelbagai, nilai pemendapan maksimum ialah $2.67 \mathrm{~cm}$, iaitu 42.1\% lebih rendah daripada nilai tanpa kaedah kawalan dan kesan kawalannya adalah jelas. Di samping itu, sokongan awal dua lapisan dan penambahan kaki gerbang besar mempunyai kesan terbaik untuk mengawal pemendapan permukaan tanah dengan pengurangan sebanyak $11.7 \%$ dan 20.2\%. Keputusan penyelidikan dapat memberikan pengalaman praktik bagi pembinaan terowong tersebut, serta membimbing reka bentuk dan pembinaan terowong pada masa hadapan.

Kata kunci: Deformasi batu; kaedah kawalan gabungan; pemantauan ubah bentuk terowong jangka panjang; tanah lembut-atas dan keras-bawah; simulasi berangka $3 D$

\section{INTRODUCTION}

With the development of social economy, many large and medium-sized cities have started a large-scale subway construction (Chadwick 2015; Issaka \& Ashraf 2017; Nasri \& Haynes 2015). Due to the buried depth and large excavation section, the stability of surrounding rock ability in the shallow tunnel large-span subway station is poor, prone to large deformation of surrounding rock so as to lead to the insatiability of the excavation face and serious cases will lead to the deformation and destruction of the ground structure, especially for the upper-soft and lowerhard ground. How to ensure the stability of the surrounding 
rock, control the deformation of the overburden is related to the safety of the tunnel construction and the surrounding environment (Hong 2015; Xia et al. 2016). The superimposed bearing arch method is a new construction method for shallow buried large span tunnel in upper and soft hard rock strata. In the arch section of the tunnel, double arch initial support is used to form a composite arch with arch structure. In recent years, Guangzhou, Qingdao and Chongqing have carried out some experimental research for the construction method in the construction of subway, but have not yet formed system theory and design method, and experience is still very limited (Esen Sze et al. 2016; Hong 2015; Richard et al. 2016; Roslee et al. 2017; Zhang \& Qiu 2015; Zhu 2015)

This paper relies on the construction case of Hing Street station of Dalian Metro Line No. 2 and makes full use of a variety of control measures including advanced large pipe roof and small pipe grouting, double initial support, additional arch foot, later radial grouting and arch rock body grouting reinforcement to control the deformation of surrounding rock and to better ensure the stability of the tunnel. Based on the analysis of the construction effect of combined degeneration control measures, the mechanism of control measures is clarified and the effect of deformation control on site is analyzed with monitoring measurement.

\section{Project OVERVIEW}

Hing Street station is located at the intersection of Xi'an Road and Hing Street, which is just under Xi'an Road. The total length of the station is $208.3 \mathrm{~m}$ and the overall structure is single arch double-story reinforced concrete frame structure. The main standard cross-section contour of the station has a width $21.2 \mathrm{~m}$, height $17.96 \mathrm{~m}$ and depth $8 \mathrm{~m}$. The standard cross-section excavation width of the station is $21.5 \mathrm{~m}$, the height is $18.11 \mathrm{~m}$, the depth of the roof is $7.18 \sim 11.75 \mathrm{~m}$ and the excavation crosssectional area is $344 \mathrm{~m}^{2}$.

The geological environment of the tunnel is mainly above the Proterozoic and Paleozoic strata, while the Mesozoic and Cenozoic strata are not developed. The ground elevation is 18.12 22.44 m and the limestone, slate, dolomitic limestone, marlite and quartz slate are mainly exposed. The main part of the station arch is dominated by strongly weathered diabase and Calcareous slate, with typical soft upper and lower hard stratum structure, as shown in Figure 1. Most of the surrounding rock types are grade IV $\sim \mathrm{V}$ and the groundwater depth is $3 \sim 4.8 \mathrm{~m}$. Because the underground pipeline is staggered and dense, the station tunnel selects the method of underground excavation. The construction method is 'double-side guide hole method + step method' and the composite lining structure is constructed. In order to ensure the stability of

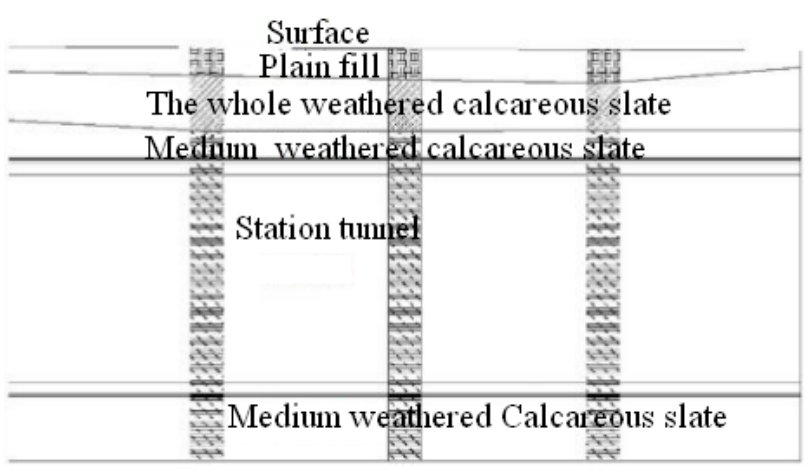

FIGURE 1. Tunnel geological profile

the surrounding rock and control the deformation of the overlying strata, in the construction process, Hing Street station used superimposed bearing arch method and supplemented by sidewall arching, the addition of large arch foot, ahead of large pipe shed and small pipe Grouting, radial grouting in the arch, grouting reinforcement in the rockmass at the bottom of the stringers and other technical measures.

\section{EFFECT ANALYSIS OF MULTIPLE SUPPORTING MEASURES}

In order to find out the control effect of all kinds of support and control measures, the numerical simulation is used to analyze. It is assumed that the rock mass is homogeneous continuum, isotropic and yield condition is D-P criterion. The required physical and mechanical parameters of the material size for numerical calculation is determined according to the field geological survey data and the point load test. Midas GTS is a numerical analysis software that performs well in tunnel engineering. The test section at DK15 + 623 DK15 + 650 linear is selected as the research object, and a 3D finite element numerical model is established using Midas GTS software. The model is shown in Figure 2.

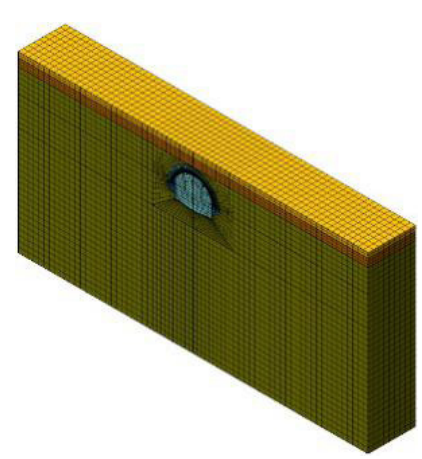

FIGURE 2. Three-dimensional numerical model 


\section{CONTRAST ANALYSIS OF SURROUNDING ROCKS DISPLACEMENT FIELD}

Surrounding rock displacement nephogram can directly reflect the distribution of displacement. Through the analysis of displacement distribution, it can be used to guide grouting of surrounding rock and initial support, and can also visually find the deformation due to tunnel excavation on the surrounding buildings and underground pipeline influence degree, therefore, analysis of displacement of surrounding rock of tunnel excavation is necessary. The displacement analysis results are shown in Figures 3-4, respectively.

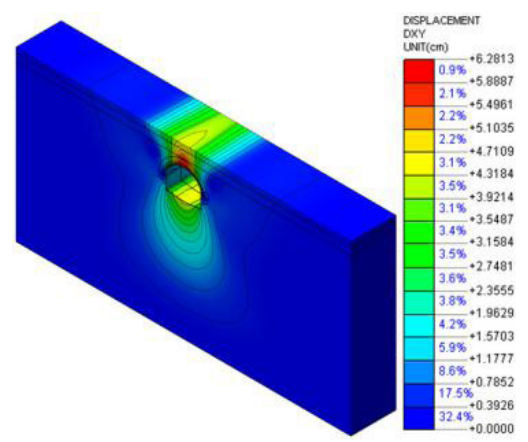

FIGURE 3. Total displacement without support

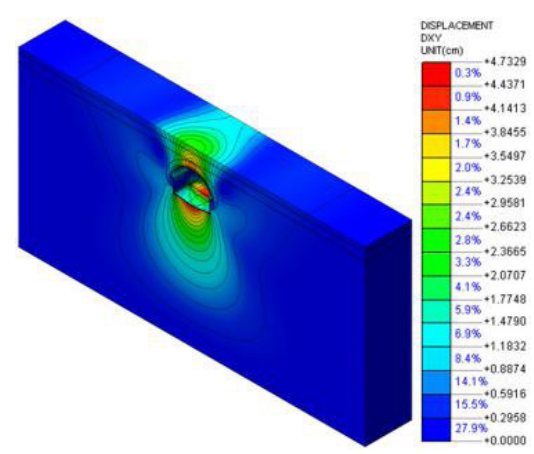

FIGURE 4. Total displacement with support

As can be seen from Figures 3-4, the deformation of the upper part of the tunnel mainly occurs in about 0 . 5 times of the hole diameter on the left and right sides without any support. The deformation of the upper part of the tunnel mainly occurs in the condition of comprehensive support. In the vicinity of the two sides of the tunnel, compared with the impact of non-supporting settlement of the case is smaller, indicating support for the control of subsidence of the formation of this effect is consistent with the actual situation, the upper wall rock downward wedges downward trend; In this two cases, the surrounding rock of the lower part of the tunnel is uplifted upward, and the middle deformation is the largest. The smaller the depth is, the smaller the radius is.

\section{CONTRAST ANALYSIS OF VARIATION LAW OF VECTOR MAP OF SURROUNDING ROCK}

Figures 5-6 represent total displacement vector diagrams under the excavation of the tunnel. It can be seen from Figures 5-6 that the surrounding rock around the tunnel has a tendency to converge to the inside of the tunnel, especially in the arch and invert.

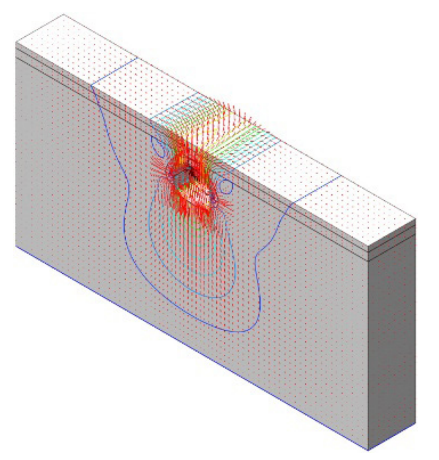

FIGURE 5. Total displacement vector without support

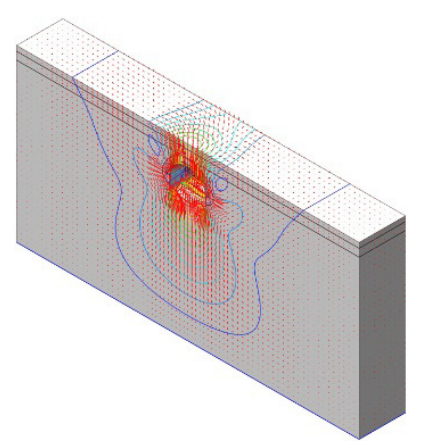

FIGURE 6. Total displacement vector with support

\section{CONTRAST ANALYSIS OF SURFACE SUBSIDENCE}

In order to study the effectiveness of each supporting measure in controlling ground surface settlement and surface horizontal displacement, the following seven kinds of working conditions were established for analysis according to the practical application of the supporting measures in Hing Street station tunnel of Dalian subway.

Case 1: without any support; Case 2: side wall invert; Case 3: side arch invert \& double initial support; Case 4: side arch invert, double initial support \& additional large arch foot; Case 5: side arch invert, double initial support, additional large arch foot \& pipe shed and small pipe grouting; Case 6: side arch invert, double initial support, additional large arch foot, pipe shed with small pipe grouting \& arch radial grouting; and Case 7: side arch invert, double initial support, additional large arch foot, pipe shed with small pipe grouting, arch radial grouting \& vertical beam bottom grouting reinforcement .

After the completion of the tunnel excavation at crosssection $\mathrm{Y}=0 \mathrm{~m}$, the surface settlement curves were shown in Figure 7. 


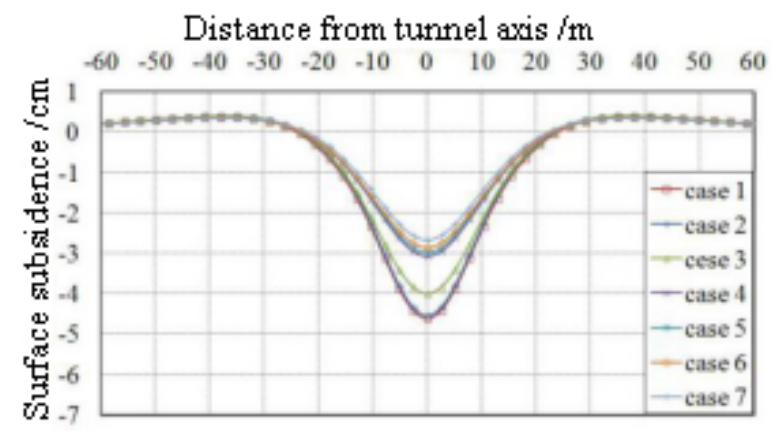

FIGURE 7. Surface subsidence curve after completion of tunnel excavation $(\mathrm{Y}=0 \mathrm{~m})$

It can be seen from Figure 7 that the surface subsidence curves of $\mathrm{Y}=0 \mathrm{~m}$ in case 1 and different combinations of support measures (Case 2-7) after tunnel excavation is basically the same. The surface subsidence mainly occurs in $\pm 24 \mathrm{~m}$ width of the outer edge of the tunnel center and the settlement tank is about $48 \mathrm{~m}$. There was no difference in the size of the settlement tank, which is due to tunnel symmetry excavation and the excavation caused by the surface settlement of the symmetrical distribution. The subsidence curves are symmetrical about the longitudinal axis and the middle is big on both sides. The farther away from the axis of the tunnel, the surface subsidence gradually decreases, the distance from the central axis of the settlement tends to 0 . In the distance from the tunnel axis $24 \sim 60 \mathrm{~m}$, the surface subsidence is positive, that is, the surface uplift.

The surface subsidence is the largest at the axial position of the tunnel and the maximum settlement of the surface is $4.61 \mathrm{~cm}$ without any support. With the gradual increase of the supporting measures, the maximum settlement on the ground surface is $2.67 \mathrm{~cm}$, which is $42.1 \%$ less than that without control, which indicates that the supporting measures have obvious effect on the surface

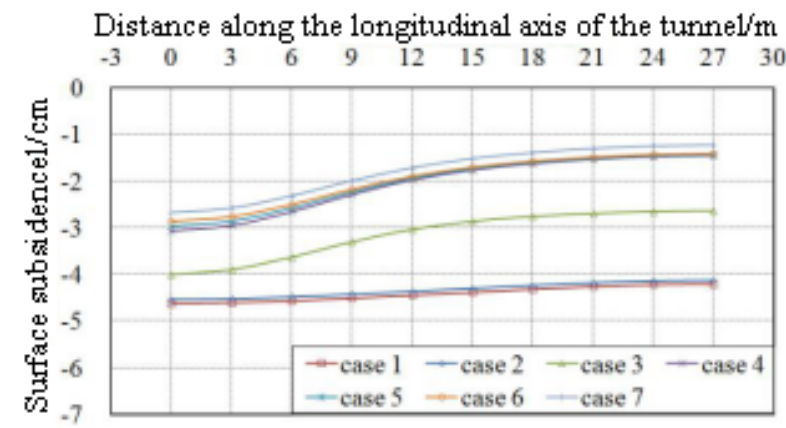

FIGURE 8. Settlement curve along the longitudinal axis after tunnel excavation $(\mathrm{Y}=0 \mathrm{~m})$ settlement control.

\section{COMPARISON AND ANALYSIS OF SETTLEMENT CURVE OF SURFACE LONGITUDINAL}

The settlement of surface longitudinal is an important mechanics index to describe the construction effect of tunnel. The settlement curves which is along the longitudinal axis after tunnel excavation at cross-sectional $\mathrm{Y}=0 \mathrm{~m}$ are shown in Figure 8.

The curves of subsidence along the longitudinal axis are basically the same in the absence of any support (Case 1) and the different combinations of support measures (Case 2-7). The maximum vertical settlement gradually reduced, because with the tunnel excavation, the settlement of the strata become much more fully, which is in line with the actual. However, the difference of the maximum settlement between the two ends of tunnel excavation is larger because of the stress release and deformation of tunnel surrounding rock, which is restrained by the supporting structure. Therefore, the maximum settlement difference between the two ends of the tunnel is quite different.

With the application of the support measures, the surface subsidence value at the same cross section decreases gradually, which indicates that the supporting measures play a role.

The maximum settlement on the surface of the tunnel is $4.61 \mathrm{~cm}$ without any support, and the maximum settlement on the surface is $2.67 \mathrm{~cm}$, which is $42.1 \%$ less than that at the tunnel end. The maximum settlement of ground surface is $4.20 \mathrm{~cm}$ without any support and the maximum subsidence is $1.23 \mathrm{~cm}$, which is $70.7 \%$ less than that of the control. The results showed that the control effect of the supporting measures on surface settlement is obvious, and the control effect at the end of the tunnel is better than at the start.

\section{CONTRAST ANALYSIS OF HORIZONTAL DISPLACEMENT CURVE}

The settlement curve along the longitudinal axis at crosssection $\mathrm{Y}=0 \mathrm{~m}$ after tunnel excavation is shown in Figure

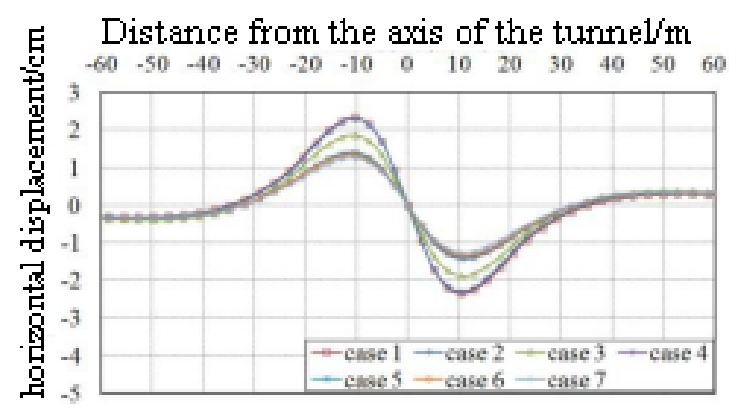

FIGURE 9. Horizontal displacement curve of surface $(\mathrm{Y}=0 \mathrm{~m})$ 
9.

The horizontal displacement curve at the cross section $\mathrm{Y}=0 \mathrm{~m}$ after tunnel excavation is basically the same in the absence of any support (Case 1) and the different combinations of support measures (Case 2-7). The curve of the curve is similar to the Centro symmetric decay function curve. The horizontal displacement of the surface in the range of $0 \sim 34 \mathrm{~m}$ near the central axis of the tunnel converges toward the center line of the tunnel and after the distance of $34 \mathrm{~m}$, the horizontal displacement decreases gradually to 0 .

With the application of the support measures, the horizontal displacement at the same cross-section gradually decreases, indicating that the support measures played a role.

The maximum horizontal displacement is about 10.3 $\mathrm{m}$ from the axis of the tunnel, the maximum horizontal displacement is $2.33 \mathrm{~cm}$ without any support and the maximum horizontal displacement of the surface is 1.25 $\mathrm{cm}$ in the case of all kinds of support which is $46.4 \%$ lower than that of the control, which indicates that the supporting measures have obvious effect on the horizontal displacement of the restrained surface.

\section{CONTRAST ANALYSIS OF THE MAXIMUM SETTLEMENT AND HORIZONTAL DISPLACEMENT}

According to the results of three-dimensional model without any support conditions and different supporting measures, the maximum subsidence value and the maximum horizontal displacement value under different working conditions after excavation are extracted. The effects of each support measures on decreasing surface subsidence and horizontal displacement is shown in the table below.

According to the data in Table 1, the curves of the maximum settlement value of the ground surface after the tunnel excavation is completed in each working condition as shown in Figure 10 and the maximum horizontal displacement value curve of the tunnel after excavation is shown in Figure 11.

As shown in Table 1 and Figure 10, the maximum subsidence value of surface subsidence decreases with the increasing of supporting measures and the maximum subsidence value is $4.61 \mathrm{~cm}$ without any control (Case 1). From the reduction percentage of surface settlement, it can be seen that the surface subsidence of the surface subsidence is relatively low. The results showed that the effect of the two-layer initial support and the large arch foot on the control of surface settlement is the best with a reduction of $11.7 \%$ and $20.2 \%$, respectively; the side wall invert, the pipe and the small pipe grouting, the radial grouting and the effect of slurry reinforcement on the control of surface subsidence is generally less than $5 \%$. This is because the numerical simulation grouting reinforcement is realized by improving the physical and mechanical parameters of the relevant soil to weaken the

TABLE 1. Maximum subsidence and horizontal displacement under different working conditions

\begin{tabular}{lllllll}
\hline \multirow{2}{*}{$\begin{array}{l}\text { Operating } \\
\text { condition }\end{array}$} & \multicolumn{2}{l}{ Surface subsidence } & \multicolumn{3}{l}{ Horizontal displacement } \\
\cline { 2 - 6 } & $\begin{array}{l}\text { maximum } \\
\text { /cm }\end{array}$ & $\begin{array}{l}\text { Cumulative } \\
\text { settlement }\end{array}$ & $\begin{array}{l}\text { settlement } \\
\text { reduction }\end{array}$ & $\begin{array}{l}\text { Maximum } \\
\text { /mm }\end{array}$ & $\begin{array}{l}\text { Cumulative } \\
\text { displacement }\end{array}$ & $\begin{array}{l}\text { Displacement } \\
\text { reduction }\end{array}$ \\
\hline case1 & 4.61 & - & - & 2.33 & - & - \\
case2 & 4.53 & $1.7 \%$ & $1.7 \%$ & 2.30 & $1.3 \%$ & $1.3 \%$ \\
case3 & 3.99 & $13.4 \%$ & $11.7 \%$ & 1.87 & $19.7 \%$ & $18.4 \%$ \\
case4 & 3.06 & $33.6 \%$ & $20.2 \%$ & 1.40 & $39.9 \%$ & $20.2 \%$ \\
case5 & 2.97 & $35.6 \%$ & $2.0 \%$ & 1.37 & $41.2 \%$ & $1.3 \%$ \\
case6 & 2.86 & $38.0 \%$ & $2.4 \%$ & 1.33 & $42.9 \%$ & $1.7 \%$ \\
case7 & 2.67 & $42.1 \%$ & $4.1 \%$ & 1.25 & $46.4 \%$ & $3.5 \%$ \\
\hline
\end{tabular}

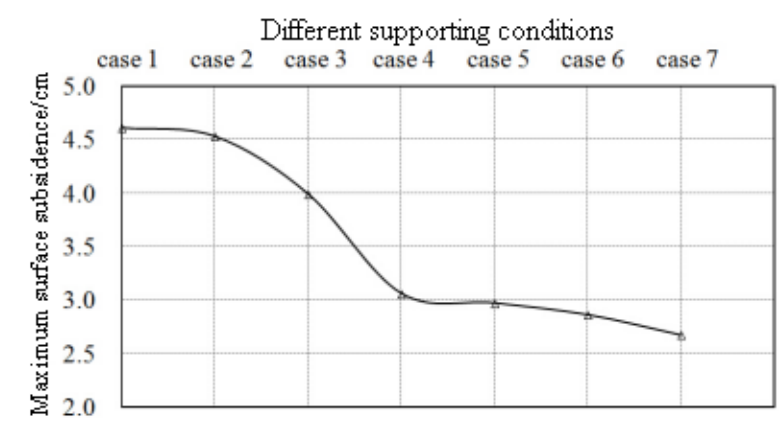

FIGURE 10. The maximum surface settlement after tunnel excavation in each working condition

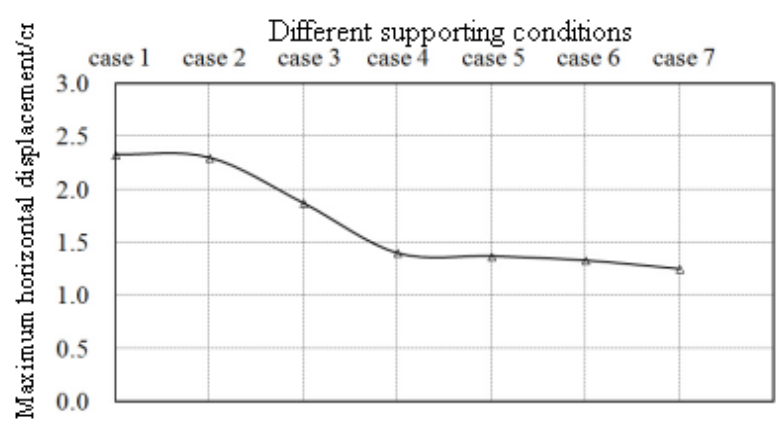

FIGURE 11. The maximum surface horizontal displacement after tunnel excavation 
actual supporting effect of the above four kinds support.

As can be seen from Table 1 and Figure 11, with the increasing of the supporting measures, the maximum horizontal displacement value of the ground surface decreases gradually and the maximum horizontal displacement value of the surface is $2.33 \mathrm{~cm}$ without any support (Case 1). In the case of applying various supports, the maximum horizontal displacement of the surface is reduced to $1.25 \mathrm{~cm}$. Compared with a decrease of $46.4 \%$, the control effect is obvious.

From the percentages of the horizontal displacement control of each measure, it can be seen that the effect of the initial support and the addition of large arch foot on the horizontal displacement of the surface are the best with reduction of $18.4 \%$ and $20.2 \%$, respectively. The effects of grouting with grouting and small pipe grouting, radial grouting of arch and reinforcement of bottom grouting on the ground surface are generally less than $4 \%$, which is due to the numerical simulation of grouting reinforcement by improving the soil physical mechanical parameters to achieve, weakening the above four kinds of supporting measures of the actual support effect.

\section{ENGINEERING VALIDATION OF DEFORMATION CONTROL}

On-site monitoring is the most direct and effective means to grasp the real surrounding rock pressure and supporting effect. Through the actual monitoring of surrounding rock and surface deformation, it can help to analyze whether the support structures play the role of supporting and judge the stability of surrounding rock and the effect of deformation control measures (Lerner et al. 2015; Li et al. 2011; Moffat et al. 2015; Rabensteiner \& Chmelina 2016; Yu et al. 2015; Zainordin et al. 2017).

\section{MONITORING PROGRAM}

In Hing station construction process, six test monitoring sections were set up and a systematic deformation monitoring was carried out. In addition, in each monitoring section, a multi-point displacement meter was also set up to monitor the internal displacement of the tunnel vault. The vault settlement of tunnel station is measured by the method of leveling (Trimble Dini03) and the instruments of leveling instrument, steel rulers or total station are equipped with. The layout mode of measuring points of the tunnel vaults are shown in Figure 12.

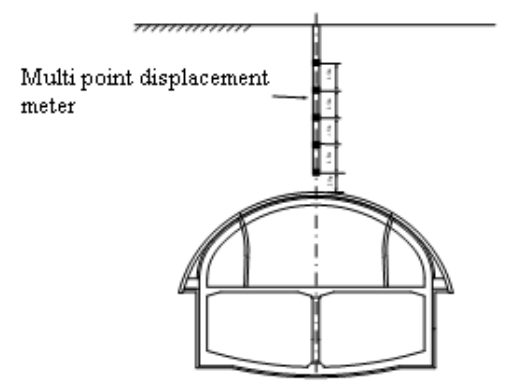

FIGURE 12. Multi-point displacement meter layout location diagram

\section{TUNNEL VAULT SINKING AND HORIZONTAL CONVERGENCE}

The tunnel arch is constructed by double-side guide-tunnel method. The excavation sequence is right guide hole-left guide hole-middle core soil. The excavation of the two side guide holes is excavated by the step method from large mileage to small mileage. The horizontal convergence of the left and right side guide holes with time is shown in Figure 13, only the convergence of the side tunnel is monitored and the convergence and variation of the whole tunnel cannot be known.

It can be seen that whether the left guide hole or the right guide hole, whether on the step or the next step, the convergence law of the monitoring section is basically the same. The level of convergence increased gradually with the distance far from excavation face and monitoring days increasing, but the increasing rate gradually decreases. The DK15+655 section is the largest, the DK15+605 section is the smallest, and the maximum level converges to 25 $\mathrm{mm}$. The convergence value shown in the Figure 13 is only the deformation value at the initial stage of the excavation of the side guide tunnel, and cannot reflect the overall convergence of the tunnel.

The monitoring results of the vaults of the side guide vaults during the excavation of the side guide holes are shown in Figure 14.

It can be seen from Figure 14 that the change rule of the vault subsidence of the two side guide vaults with the excavation and the time course is very similar to the horizontal convergence. The sag of the right guide hole is obviously larger than that of the left guide hole. The maximum sinking of the right guide hole is about $35 \mathrm{~mm}$, while the maximum sinking of the left guide hole is only $18 \mathrm{~mm}$. This is related to the later excavation of the left guide hole and the short monitoring time. It can be seen from the sinking curve of the left guide hole that, at the end of the monitoring, the vault subsidence has not stabilized and continues to develop at a certain growth rate.

Figure 15 is the curve of the central core soil excavation of the tunnel arch (i.e. the three excavations) and the subsidence of the central crown of the tunnel after completion of the initial inner support. Due to the excavation of the two side guide holes during the excavation of the central core soil and support has been completed, although the left and right sides of the temporary support has not been removed, because of the tunnel span, the initial support after the second floor vault sinking continues. After nearly four months the vault sinking gradually became stably.

\section{SURFACE SUBSIDENCE}

Two surface subsidence lines were laid in each of the three test sections and four survey points were set up for each 

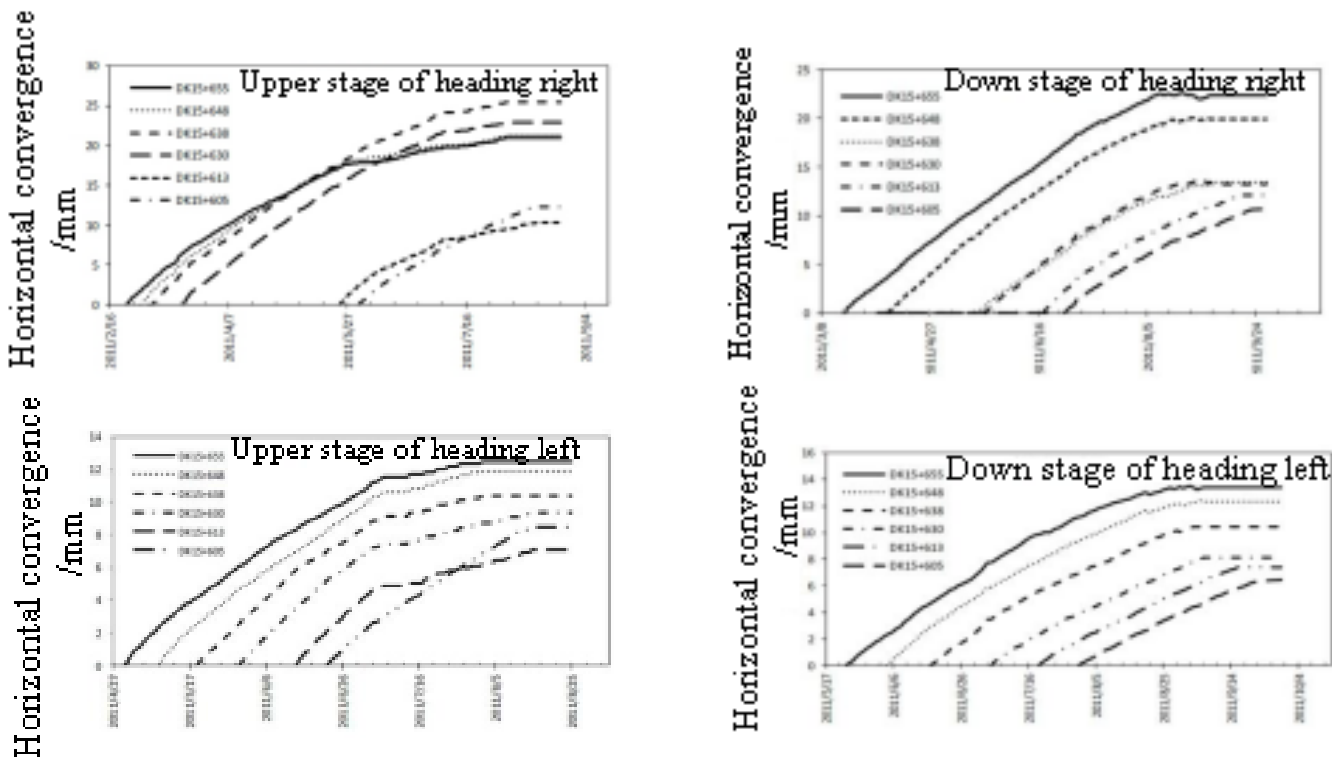

FIGURE 13. Horizontal convergence time-history curve of left-right excavation
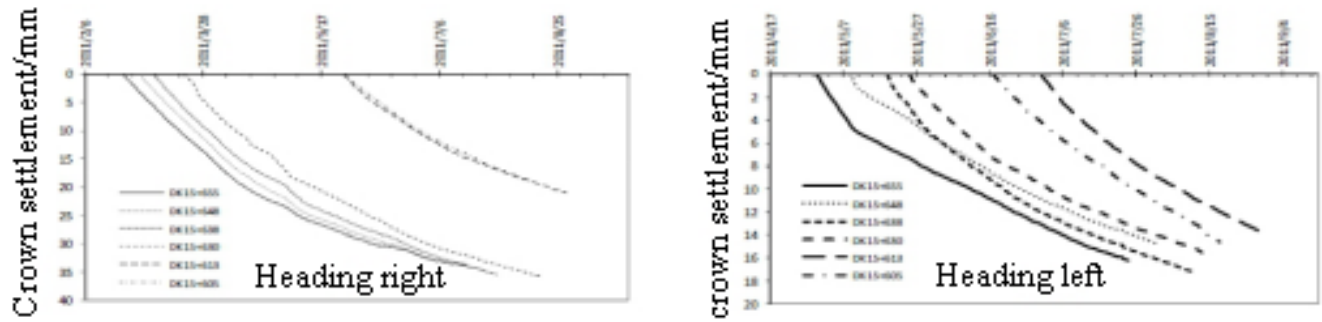

FIGURE 14. Curve of sinking time of two-side guide vaults

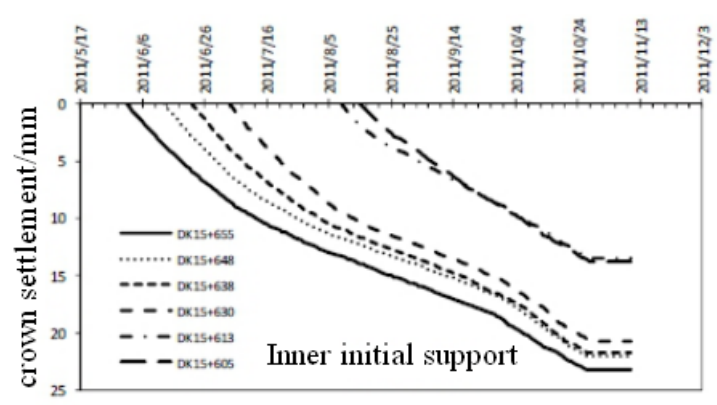

FIGURE 15 . Time history curve of the central vault after the inner initial support

line. The distance between the two lines was DK15+638 and DK15+655, respectively. Four monitoring points located above the surface of the tunnel, in which monitoring points 1 and 4 located above the surface of the excavation profile on the left and right sides of the tunnel, respectively. The surface subsidence curves of each measuring point on the two lines are shown in Figures 16-17, respectively.

It can be seen that the maximum settlement of DK $15+635$ section is $69.2 \mathrm{~mm}$ and the maximum settlement of DK15+655 section is $83.1 \mathrm{~mm}$. Although the settlement of two lines is different, the variation of settlement is almost the same. The subsidence of four points on each line is very close, which indicates the overall settlement has occurred in the surface above the vault.

\section{COMPARISON OF NUMERICAL SIMULATION RESULTS AND ON-SITE MONITORING RESULTS}

Figure 18 shows the comparison of the settlement curves of DK15+638 surface with three-dimensional finite element method. The characteristics and regularity of tunnel surface settlement can be found out.

After tunnel excavation, the measured maximum displacement of the $3^{\#}$ measuring point is $70.2 \mathrm{~mm}$ and the maximum displacement of the numerical simulation is 26.7 $\mathrm{mm}$, with a difference of $43.5 \mathrm{~mm}$. Because the numerical simulation cannot consider the local discontinuity of soil, in addition groundwater and surface dynamic load, the results of the two results in the numerical deviation and the measured results is greater than the numerical simulation results.

The measured surface subsidence curves of $1^{\#}, 2^{\#}, 3^{\#}$, and $4^{\#}$ show only slight fluctuation, almost coinciding with each other, indicating the overall settlement after tunnel excavation.

From the curve trend, the measured results are 


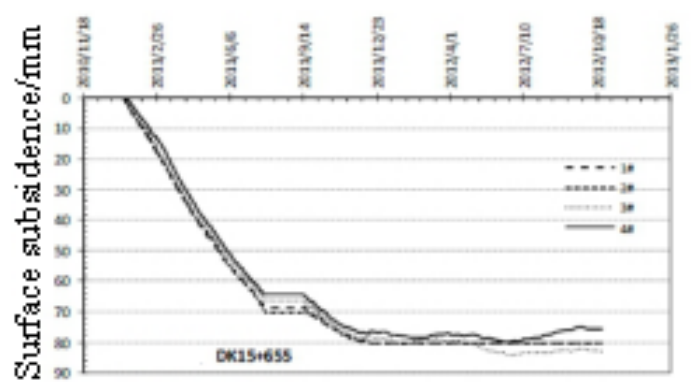

FIGURE 16. Surface subsidence time-history curve (DK15+638)

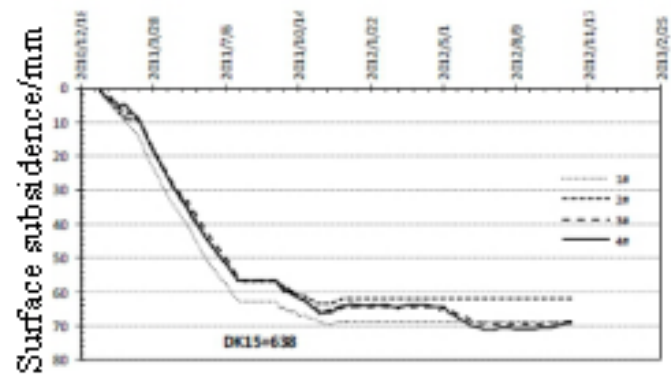

FIGURE 17. Surface settlement time-history curve (DK15+655)

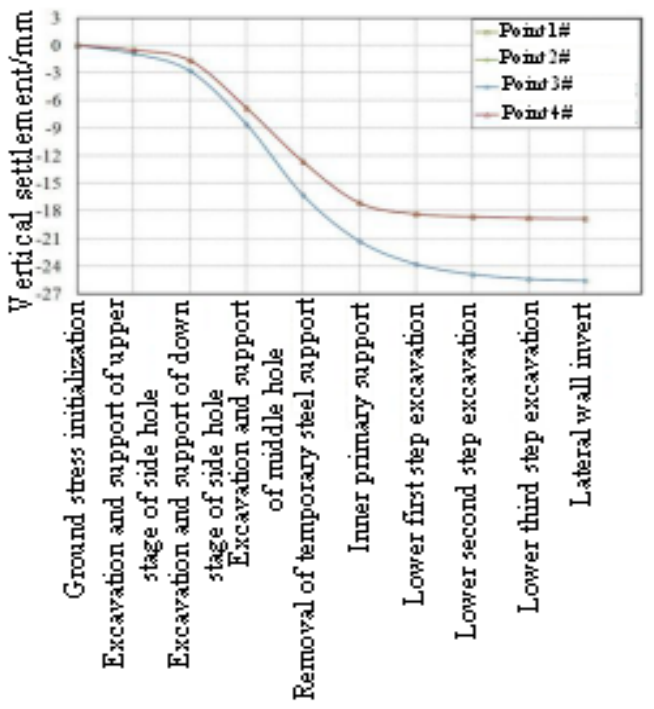

FIGURE 18. Measured surface settlement curve and numerical simulation subsidence curve

very similar to the numerical simulation of the surface subsidence, which proves the rationality of the numerical simulation results.

From the side hole on the stage to the initial stage of excavation to support the construction of the initial stage of the completion of the construction phase, surface subsidence develop rapidly, i.e. the construction of tunnel arch caused the largest settlement, which is the main cause of surface subsidence. After excavation and support of the arch, the excavation of the lower part of the tunnel caused less surface settlement. This is related to the quality of the surrounding rock mass of the cave section being better than the arch, but also to the arch of the two-stage initial support, arch reinforcement, anchor and anchor reinforcement and other support measures.

\section{ConClusion}

During the tunnel excavation, different types of surrounding rock will be encountered. For the surrounding rock with good stability, after excavation of the tunnel, the surrounding rock has a certain self-stabilization time to ensure that the initial support has sufficient to do. The initial support should bear the full load of the tunnel excavation. For the surrounding rocks with poor stability, after the excavation of the tunnel, the self-stabilization time of the surrounding rock is very short and the initial supporting capacity of the surrounding rock is very short. In such surrounding rock, advanced support measures should be adopted to reduce the load that may be released after excavation.

The tunnel of Hing station in Dalian subway is in the upper soft and lower hard underground strata. The geological condition is poor, the underground pipeline is complex and the ground surface has buildings which require for settlement control. In order to control the surface subsidence and tunnel deformation, the 'rigid structure control concept' design is used. By strengthening the supporting structure of the stiffness and improving the bearing capacity of the surrounding rock the deformation is controlled. Concrete measures include the side wall invert, the double initial support, the addition of large arch foot, ahead of large pipe shed and small pipe grouting, arch radial grouting and groin rock reinforcement.

From analysis of the above six kinds of support measures, it shows that the maximum surface subsidence value is gradually reduced with the support measures gradually increasing. Without any support (Case 1), the maximum surface sedimentation value is $4.61 \mathrm{~cm}$, in the case of various supports the maximum sedimentation value is $2.67 \mathrm{~cm}$, which is $42.1 \%$ lower than that of not using control method and the control effect is obvious. From the percentage of controlling surface subsidence, it can be seen that the two-layer initial support and additional large arch foot has the best effect on controlling the ground surface settlement with reduction of $11.7 \%$ and $20.2 \%$, respectively. The sidewall arching, the pipe shed and the small pipe grouting, the arch grouting and the longitudinal grouting has common effect on controlling surface subsidence, which is less than $5 \%$ and this is because the numerical simulation of grouting reinforcement is achieved by improving the physical and mechanical parameters of the relevant soil so as to weaken the above four kinds of supporting measures of the actual support effect.

The presented construction method in this paper can be used for other tunnel station in different regions, such as rich water tunnel and soft rock tunnel. 
This study is subsidized by the Science and Technology Project of Hebei Province (Grant No. 16215408D); Hebei Provincial Disaster Prevention and Mitigation Collaborative Innovation Center of Large Infrastructure Projects and Hebei Provincial Key Disciplines Funded Construction Projects (Geotechnical Engineering). These financial supports are gratefully acknowledged.

\section{REFERENCES}

Chadwick, S. 2015. Bond street station upgrade - using 3D analysis to optimise tunnel design. Structural Engineer 93(7): 24-26.

Esen Sze, Y.S., Jim Yee, T.C., Henry Kim, I., Osborne, N.H., Chang, K.B. \& Siew, R. 2016. Tunnelling undercrossing existing live MRT tunnels. Tunnelling and Underground Space Technology 57: 241-256.

Hong, K.R. 2015. State-of-art and prospect of tunnels and underground works in China. Tunnel Construction 35(2): 95-107.

Issaka, S. \& Ashraf, M.A. 2017. Impact of soil erosion and degradation on water quality: A review. Geology, Ecology, and Landscapes 1(1): 1-11.

Lerner, U., Yacobi, T., Levy, I., Moltchanov, S.A., ColeHunter, T. \& Fishbain, B. 2015. The effect of egomotion on environmental monitoring. Science of the Total Environment 533: 8-16.

Li, X.Z., Li, S.C. \& Li, S.C. 2011. A study on surface subsidence and deformation characteristics during construction of shallow buried large span tunnel. Journal of Rock Mechanics and Engineering 30(S1): 3348-3353.

Moffat, R.A., Beltran, J.F. \& Herrera, R. 2015. Applications of BOTDR fiber optics to the monitoring of underground structures. Geomechanics and Engineering 9(3): 397-414.

Nasri, V. \& Haynes, C.E. 2015. New tunnel system to eliminate sanitary sewer overflows and control combined sewer overflows in Hartford, Connecticut. Water Practice and Technology 10(2): 282-290.

Rabensteiner, K. \& Chmelina, K. 2016. Tunnel monitoring in urban environments. Geomechanik und Tunnelbau 9(1): 23-28.

Richards, D.J., Wiggan, C.A. \& Powrie, W. 2016. Seepage and pore pressures around contiguous pile retaining walls. Geotechnique 66(7): 523-532.

Roslee, R., Bidin, K., Musta, B., Tahir, S., Tongku, F. \& Norhisham, M.N. 2017. GIS application for comprehensive spatial soil erosion analysis with MUSLE model in Sandakan town area, Sabah, Malaysia. Geological Behavior 1(1): 1-5.

Xia, C.C., Na, T. X., Peng, G.C. \& Chen, Z.Q. 2016. Discussion on deformation monitoring accuracy of highway tunnel construction. Tunnel Construction 36(5): 508-512.
Yu, J., Standing, J., Vollum, R., Potts, D. \& Burland, J. 2015. Stress and strain monitoring at Tottenham court road station, London, UK. Proceedings of the Institution of Civil Engineers: Structures and Buildings 168(2): 107-117.

Zainordin, N.S., Ramli, N.A. \& Elbayoumi, M. 2017. Distribution and temporal behaviour of $\mathrm{O} 3$ and $\mathrm{NO} 2$ near selected schools in Seberang Perai, Pulau Pinang and Parit Buntar, Perak, Malaysia. Sains Malaysiana 46(2): 197-207.

Zhang, Z.G. \& Qiu, W.G. 2015. Discussion and case study of the rational ratio of rock mass thickness and tunnel span of mined subway tunnels in upper-soft and lower-hard ground. Modern Tunneling Technology 52(6): 28-42.

Zhu, H.H. 2015. Design and construction of shield-bored metro tunnels in hard-soft heterogeneous ground. Tunnel Construction 35(2): 144-148.

Yanliang Shang \& Shouji Du*

Department of Civil Engineering

Shanghai Jiao Tong University

Shanghai 200240

China

Yanliang Shang

Key Laboratory of Roads and Railway Engineering

Safety Control of Ministry of Education

Shijiazhuang Tiedao University

Shijiazhuang 050043

China

Tongyin Han

Party Committee

Langfang Teachers University

Langfang 065000

China

Biao Shao

Urban Rail Design Institute

The Third Railway Survey and Design Institute Group

Corporation

Tianjin 300142

China

*Corresponding author; email: sty1980926@163.com

Received: 8 February 2017

Accepted: 9 June 2017 